\title{
Covid-19, Investor Sentiment and Contagion across Stock Markets
}

Araştırma Makalesi /Research Article

\author{
Mehmet Fatih BUĞAN ${ }^{1}$
}

\begin{abstract}
This study examines investor sentiment which may trigger contagion in financial markets during the recent Covid-19 outbreak within a DCC-GARCH model. The results show that most of the time-varying correlations have risen after the Covid-19 outbreak until the WHO declared the disease as a global pandemic and most of the rise in correlations occurs within each group of countries/regions where the least and the most deaths took place. There is evidence of contagion in most cases. Overall, investor sentiment seems to give rise to contagion as the correlations between stock markets have increased during the global Covid-19 pandemic.
\end{abstract}

Keywords: Equity Market Correlations, Contagion, Investor Sentiment, Covid-19 Impact Studies

JEL Classification: G10, G15, G40

\section{Covid-19, Yatırımcı Duyarlılığı ve Pay Piyasaları Arasında Bulaşma Etkisi}

ÖZ: $\mathrm{Bu}$ çalışmada, finansal piyasalar arasında bulaşma etkisine neden olabilecek yatırımc1 duyarlılığı, Covid-19 salgın dönemi için DCC-GARCH modeli ile incelenmektedir. Çalışmadan elde edilen bulgular, Dünya Sağlık Örgütü'nün Covid-19'u bulaşıcı bir salgın hastalık olarak ilan ettikten sonra ölüm oranı en düşük ve en yüksek ülkeler arasındaki zamanla değişen korelasyon katsayılarının arttığını göstermektedir. Çoğu durumda bulaşma etkinin olduğuna dair kanitlar elde edilmiştir. Genel olarak, yatırımcı duyarlılığının Covid-19 salgın döneminde pay piyasaları arasındaki korelasyonu artırmak suretiyle bulaşma etkisine neden olduğu görülmektedir.

Anahtar Kelimeler: Pay Piyasası Korelasyonları, Bulaşma Etkisi, Yatırımcı Duyarlılığı, Covid-19 Etkisi Çalışmaları

JEL Sinıflandırması: G10, G15, G40

Geliş Tarihi / Received: 04/02/2021

Kabul Tarihi / Accepted: 14/04/2021

1 Dr., Assistant Professor, Gaziantep University, Faculty of Economics and Administrative Sciences, mfbugan@gantep.edu.tr, https://orcid.org/0000-0001-9027-9532 


\section{Introduction}

After first appearing in Wuhan, China in late 2019, the novel coronavirus has wreaked havoc worldwide in a relatively short period of time. The World Health Organization (WHO) declared the coronavirus (Covid-19) as a pandemic on March 11, 2020. As of January 03, 2021, as many as 213 countries and territories have been affected by Covid-19 and the total number of cases of Covid-19 have reached nearly 84 million, while the number of deaths from Covid-19 has reached nearly 2 million worldwide.

While the total number of cases of Covid-19 and deaths has significantly increased everywhere, its reach has been unprecedented particularly due to the extent of globalization. Yeo (2020) compares the circumstances of the SARS virus which was largely confined to East Asia in 2003 to the recent Covid-19, where no country or region was spared: today China accounts for $17 \%$ of global GDP compared to $4 \%$ in 2003 and recently Chinese tourists made 149.7 million trips worldwide compared to 20.2 million trips in 2003. As of Jan 15, 2021, the incidence and effects of Covid-19 are shown in Table 1. Per numbers in Table 1, the US has the highest cases and deaths from Covid-19, and Taiwan has the lowest. Interestingly, South-East Asia and Africa have the lowest cases of Covid19 in the current epidemic and the lowest deaths from Covid-19 happen to be in Hong Kong. Results in Table 1 highlight the importance of purported measures taken by countries in response to the epidemic.

Table 1: Incidence of COVID-19: A Comparative Sample

\begin{tabular}{llll}
\hline \hline Country & First Case Date & Total Death & Total Case \\
\hline United States of & 20.01 .2020 & 345,253 & $19,974,413$ \\
America & 26.02 .2020 & 195,411 & $7,700,578$ \\
Brazil & 30.01 .2020 & 149,435 & $10,323,965$ \\
India & 28.02 .2020 & 126,507 & $1,437,185$ \\
Mexico & 29.01 .2020 & 74,985 & $2,141,201$ \\
Italy & 23.01 .2020 & 150 & 8,965 \\
Hong Kong & 13.01 .2020 & 64 & 7,379 \\
Thailand & 23.01 .2020 & 29 & 58,662 \\
Singapore & 28.02 .2020 & 25 & 1,825 \\
New Zeeland & 29.02 .2020 & 7 & 812 \\
Taiwan & 1.12 .2019 & $1,831,412$ & $83,322,449$ \\
\hline World &
\end{tabular}

Note: All of the data was obtained from WHO (https://covid19.who.int/ ) except Taiwan and Hong Kong, which were retrieved from https://www.worldometers.info/coronavirus/. "World" gives total reported cases worldwide by WHO and the sample total does not add up due to the sample being non-comprehensive. 
Although Thailand is one of the first countries where Covid-19 appeared, it has a modest number of deaths. A similar case can be made for Singapore and Hong Kong. Taiwan and New Zealand are places where the first Covid-19 incidence appeared last.

Many countries/regions, including developed ones, were caught unprepared for the virus which put an undue burden on their health systems, particularly in some European countries. Governments at all levels took extensive measures, including quarantine, to slow the spread of the virus. Additional measures included the switch to distance education, working from home; halting domestic and international travel; closure of shopping malls, restaurants, and entertainment venues; putting on hold concerts and sports competitions; obligation to use masks, and imposing curfews (K1lıç, 2020; Çütçü and Kılıç, 2020). In addition to the effects on social life, these measures adversely affected real economic activity, trade, and financial intermediation. Sharp declines were observed in financial markets due to the unexpected pandemic that affected every sphere of everyday life. Governments introduced massive bailout packages that were partially responsible for the ongoing partial recovery which somewhat mitigated the effects on markets; however, it seems uncertainty will continue as long as the pandemic continues (Zhang et al., 2020).

The IMF called measures against Covid-19 the "Great Lockdown". According to the IMF projections, the global economy will shrink by $3 \%$ in 2020 and the Great Lockdown seems to be the worst recession since the Great Depression. Considering that global growth was $-0.1 \%$ in 2009 due to the Global Financial Crisis (GFC), the negative impact of the Great Lockdown on the global economy will be worse than the Global Financial Crisis (Gopinath, 2020). In the current crisis financial markets fared the worst in addition to the impact on the real economy. After the WHO declared Covid-19 as a global pandemic, DJIA fell $12.93 \%$ on March 16, 2020 which was the largest daily drop since 1987's Black Monday. The drop in the S\&P 500 index was approximately $12 \%$.

Specifically, we consider the Covid-19 pandemic as a major disaster and examine the effects thereof on stock markets that are mediated by investor sentiment. There is a well-documented literature that documents the effects of investor sentiment on stock markets (Shan and Gong, 2012; Corredor et al., 2013; Debata et al., 2018; Khan et al., 2019). However, investor sentiment cannot be directly observed, and hence different proxies are considered to measure investor sentiments in the literature such as trading volume, turnover ratio, consumer confidence, business confidence, and Google trend data. Kaplanski and Levy (2010) stress how investor decisions are affected by bad mood and anxiety. An increase in the anxiety of investors makes them be more pessimistic about the future and decreases their risk appetite. Kaplanski and Levy (2010) examined the effect of aviation disasters on stock prices in the US. Shan and Gong (2012) examined the effect of the earthquake on stock markets in China. As in Kaplanski 
and Levy (2010) and Shan and Gong (2012), we focus on the effects of negative emotions such as anxiety and fear on the stock markets. The total number of deaths from Covid-19 is considered a proxy for negative sentiments since Johnston and Davey (1997) empirically showed that negative coverage in media raise anxiety and prompt bad mood in people. Hence, it can be expected that negative investor sentiments are higher in countries that have the highest deaths from Covid-19 than countries with the lowest deaths. Given that investors tend to behave irrationally in turmoil periods, investor sentiment produces market correlations (Niţoi and Pochea, 2020). Since the spread of negative emotions is common in human society (Zhao et al., 2014), investor sentiment contagion effects play an important role in understanding the dynamics of stock market correlations. Huang and Zheng (2020), examine the long-run relationship between investor sentiment as proxied by the crude oil volatility index and the WTI oil futures price index. They find that there was a structural change in this relationship due to Covid-19. Akhtaruzzaman et al. (2021), examined financial contagion between China and G7 countries during the Covid-19 period. Their results show that the conditional correlations increase between stock returns. Corbet et al. (2020), investigated the Covid-19 effect on crypto currencies. They found evidence that the contagion effect also exists on cryptocurrencies. Naseem et al. (2021) stated that investor psychology was negatively related under psychological resilience and pandemic pressure. Using text sentiment analysis of Twitter data, Xia and Chen (2021) look at tweets that contain key words in relation to the COVID-19 pandemic and the sentiment of the tweet and they find a range of correlation of COVID-19 sentiment with prices.

The GFC started in the US, but soon became a worldwide crisis and precipitated simultaneous drops in stock markets. The main question of this study is to investigate whether there are grounds to believe the same dynamics are in place during the Covid-19 pandemic. Hence, we examine the conditional correlations between stock markets of countries/regions that have experienced the highest and lowest deaths from Covid-19 pre- and during the ongoing Covid-19 pandemic.

In this study, we classify countries into two groups where the first group consists of five countries with the highest deaths from Covid-19. The second group is the set of countries/regions that have the lowest deaths from Covid-19. Then, we examine the conditional correlations among the stock markets of countries in the two groups before and after the Covid-19 outbreak using a bivariate DCCGARCH model. The results allow us to ascertain whether there is a divergence between two sets of stock markets due to the Covid-19.

The rest of this paper is organized as follows: The next section provides our research methodology. Section 3 presents the data and empirical findings. Section 4 concludes the paper. 


\section{Econometric Framework}

We use a bivariate Dynamic Conditional Correlation (DCC)-GARCH model proposed by Engle (2002) to examine the effects of COVID-19 contagion on the dynamic nature of investor sentiment. The DCC-GARCH model has some advantages. First, it provides time-varying conditional correlation coefficients to test the contagion effects, if any, in both tranquil and crisis periods. Moreover, it allows dynamic correlation coefficients to be obtained through standardized residuals, considering heteroscedasticity.

DCC-GARCH model consists of a two-stage estimation process. In the first stage, the univariate GARCH model is estimated. In the second stage, dynamic conditional correlations are calculated. The bivariate DCC-GARCH model can be implemented as follows: let $y_{t} \equiv\left[y_{1 t} y_{2 t}\right]^{r}$ be a $2 \times 1$ vector containing the past observations in a conditional mean equation. The reduced-form VAR represented in the conditional mean equation as follows:

$$
A(L) y_{t}=\varepsilon_{t}, \quad \varepsilon_{t} \sim \text { Student }-t\left(0, H_{t}\right) t=1, \ldots, T
$$

where $A(L)$ is a matrix for the autoregressive coefficients, $\mathrm{L}$ is the lag operator and $\varepsilon_{t}=\left[\varepsilon_{1 t}, \varepsilon_{2 t}\right]$ is a vector of standardized residuals with the following specification;

$$
H_{t} \equiv D_{t} R_{t} D_{t}
$$

where $D_{t}=\operatorname{diag}\left\{\sqrt{h_{i t}}\right\}$ is a $2 \times 2$ diagonal matrix of time-varying standard deviation from the EGARCH $(1,1)$ models and $R_{t} \equiv\left\{\rho_{i j}\right\}_{t}$ for $i j=1,2$, which symmetric dynamic conditional correlation coefficients of the standardized residuals.

The conditional standard deviations in $D_{t}$, is obtained from the univariate EGARCH $(1,1)$ model as follows:

$\ln \left(h_{i t}\right)=\omega_{i}+\alpha_{i}\left(\left|\frac{\varepsilon_{i t-1}}{h_{t-1}}\right|-E\left|\frac{\varepsilon_{i t-1}}{h_{t-1}}\right|\right)+\gamma \frac{\varepsilon_{i t-1}}{h_{t-1}}+\beta_{i} \ln \left(h_{i t-1}\right) \quad \forall i=1,2$.

Engle (2002) showed the structure of $\operatorname{DCC}(M, N)$ as follows:

$$
R_{t}=Q_{t}^{*-1} Q_{t} Q_{t}^{*-1}
$$

where

$Q_{t}=\left(1-\sum_{m=1}^{M} \alpha_{m}-\sum_{n=1}^{N} b_{n}\right) \bar{Q}+\sum_{m=1}^{M} \alpha_{m}\left(\varepsilon_{t-m} \varepsilon_{t-m}\right)+\sum_{n=1}^{N} b_{n} Q_{t-n}$

In Equation (5), $\bar{Q}$ indicates the time-invariant conditional covariance matrix of the standardized residuals. $Q_{t}^{*}$ is a $2 \times 2$ inverted diagonal matrix with the square 
root of the diagonal elements of $Q_{t}$. The time-varying conditional correlations are calculated as $\rho_{12, t}=q_{12, t} / \sqrt{q_{11, t} q_{22, t}}$.

\section{Data and Empirical Results}

According to results in Table 1, the first group of countries with the highest deaths from Covid-19 are the US, Brazil, India, Mexico, and Italy. The second group of countries/regions consists of Hong Kong, Thailand, Singapore, New Zealand, and Taiwan. We collect the daily closing prices of equity market indices of the countries in question from the MSCI web site for the 2006-2020 period. We calculate the logarithmic return series for all the indexes using the log difference of the series: $r_{t}=\ln \left(P_{t} / P_{t-1}\right) \times 100$.

Table 2 presents summary statistics for all return series. According to the results in Table 2, the daily mean return is negative for only Italian stock market in the sample. The US stock market provides the highest daily mean return within the sample. The Brazilian stock market exhibits higher volatility according to standard deviations. It is evident that the distributions of returns series are not normal as they exhibit strong negative skewness and excess kurtosis. The unit root test results suggest that all return series are stationary in levels.

Table 2: Descriptive statistics of return series

\begin{tabular}{|c|c|c|c|c|c|c|c|c|c|c|}
\hline & Mean & Min. & Max. & $\begin{array}{l}\text { Std. } \\
\text { Dev. }\end{array}$ & Skewness & Kurtosis & Jarque-Bera & $\mathrm{ARCH}(5)$ & $\mathrm{ADF}$ & PP \\
\hline US & 0.02 & -12.92 & 11.04 & 1.25 & -0.60 & 17.19 & $33113.02 * * *$ & $315.430 * * *$ & $-20.0491 * * *$ & $-71.91 * * *$ \\
\hline Brazil & 0.00 & -19.43 & 16.62 & 2.30 & -0.57 & 12.66 & $15437.12 * * *$ & $285.300 * * *$ & $-20.2546 * * *$ & $-62.44 * * *$ \\
\hline India & 0.02 & -15.62 & 19.49 & 1.65 & -0.20 & 14.19 & $20467.24 * * *$ & $63.339 * * *$ & $-19.2794 * * *$ & $-60.45 * * *$ \\
\hline Mexico & 0.00 & -11.18 & 15.16 & 1.69 & -0.30 & 10.21 & $8541.675^{* * * *}$ & $207.510 * * *$ & $-19.2463 * * *$ & $-56.49 * * *$ \\
\hline Italy & -0.01 & -20.54 & 12.47 & 1.79 & -0.62 & 13.23 & $17318.59 * * *$ & $63.587 * * *$ & $-19.7826 * * *$ & $-63.97 * * *$ \\
\hline $\begin{array}{l}\text { Hong } \\
\text { Kong }\end{array}$ & 0.01 & -12.57 & 10.45 & 1.28 & -0.26 & 10.88 & $10172.29 * * *$ & $208.600 * * *$ & $-19.2823 * * *$ & $-61.98 * * *$ \\
\hline Thailand & 0.02 & -18.08 & 10.52 & 1.54 & -0.89 & 16.31 & $29421.8 * * *$ & $85.088 * * *$ & $-19.1921 * * *$ & $-63.25 * * *$ \\
\hline Singapore & 0.00 & -9.81 & 8.56 & 1.28 & -0.25 & 9.46 & $6862.204 * * *$ & $264.990 * * *$ & $-19.9037 * * *$ & $-61.58 * * *$ \\
\hline $\begin{array}{l}\text { New } \\
\text { Zealand }\end{array}$ & 0.01 & -10.07 & 10.20 & 1.36 & -0.39 & 8.39 & $4852.655^{* * *}$ & $224.890 * * *$ & $-19.9155 * * *$ & $-60.09 * * *$ \\
\hline Taiwan & 0.02 & -7.23 & 8.23 & 1.33 & -0.29 & 6.91 & $2552.525 * * *$ & $86.535 * * *$ & $-20.9517 * * *$ & $-60.79 * * *$ \\
\hline
\end{tabular}

Note: ARCH (5) is LM test for ARCH effect. *** indicates the significance at $1 \%$ level.

Table 3 shows the Pearson correlation statistics for the return series. Pairwise correlations between the first group countries' stock markets are higher than the second group countries' stock markets. Also, correlations between the stock markets of the countries with the least and most deaths from Covid-19 are generally low. 
Table 3: Pearson correlations between return series

\begin{tabular}{|c|c|c|c|c|c|c|c|c|c|}
\hline & US & Brazil & India & Mexico & Italy & Hong Kong & Thailand & Singapore & $\begin{array}{l}\text { New } \\
\text { Zealand }\end{array}$ \\
\hline US & 1 & & & & & & & & \\
\hline Brazil & $0.6169 * * *$ & 1 & & & & & & & \\
\hline India & $0.2930 * * *$ & $0.3779 * * *$ & 1 & & & & & & \\
\hline Mexico & $0.6465 * * *$ & $0.7171 * * *$ & $0.4061 * * *$ & 1 & & & & & \\
\hline Italy & $0.5322 * * *$ & $0.5523 * * *$ & $0.4016^{* * *}$ & $0.5978 * * *$ & 1 & & & & \\
\hline Hong Kong & $0.2384 * * *$ & $0.3560 * * *$ & $0.5253^{* * *}$ & $0.3528 * * *$ & $0.3462 * * *$ & 1 & & & \\
\hline Thailand & $0.2561 * * *$ & $0.3556 * * *$ & $0.4898 * * *$ & $0.3764 * * *$ & $0.3520 * * *$ & $0.5301 * * *$ & 1 & & \\
\hline Singapore & $0.3280 * * *$ & $0.4498 * * *$ & $0.5970 * * *$ & $0.4805^{* * *}$ & $0.4768 * * *$ & $0.7100 * * *$ & $0.5721 * * *$ & 1 & \\
\hline New Zealand & $0.2016 * * *$ & $0.3476^{* * *}$ & $0.3431^{* * *}$ & $0.3695 * * *$ & $0.4225 * * *$ & $0.3900 * * *$ & $0.3412 * * *$ & $0.4845^{* * *}$ & 1 \\
\hline Taiwan & $0.1715^{* * *}$ & $0.2882 * * *$ & $0.4407 * * *$ & $0.2828 * * *$ & $0.2750 * * *$ & $0.5969 * * *$ & $0.4401 * * *$ & $0.5909 * * *$ & $0.3737 * * *$ \\
\hline
\end{tabular}

Note: $* * *$ indicates statistically significant correlation at $1 \%$ level.

We estimate the bivariate DCC model to ascertain time-varying conditional correlations. Note that we use the EGARCH model suggested by Nelson (1991) for each return series to account for the leverage effects in estimation. We do not report here the details or results from the model and the DCC coefficients due to space constraints. ${ }^{2}$ To examine any relation between stock markets due to Covid19, we compare the mean of time-varying conditional correlations using the independent samples t-test before and after the Covid-19 outbreak.

We consider the 120-trading-day period between the onset of Covid-19 (December 01, 2019) and May 15, 2020 as the "crisis" period. Peterson (1989) states that selection of the length of the estimation period is left to the researcher but emphasizes that the typical length of the sample should be between 100 and 300 days for daily studies. In doing so, we set the number of observations to 120 days to represent the pre-crisis period (June 17, 2019 and November 29, 2019).

Figure 1 shows the time-varying conditional correlations for the first group countries' stock markets before and after the Covid-19 outbreak. The vertical line indicates the date when the first Covid-19 case appeared (December 1, 2019) and the shaded areas show the span between March 11, 2020 (Covid-19 was declared a global pandemic by the WHO) and May 15, 2020.

As can be seen from Figure 1, most of the time-varying correlations between stock markets started to increase starting in December 2019 and reached the highest level when the disease was declared a pandemic. The time-varying correlations between developed countries exceed 0.5 as of March 2020. Although time-varying correlations have started to decrease after March 2020, they are still higher than the pre-Covid-19 period. The results in Figure 2 show similar results for the countries that have the lowest deaths from Covid-19 and the time-varying correlations increased significantly during the pandemic.

\footnotetext{
${ }^{2}$ Details are available upon request.
} 
Figure 1: Time-varying conditional correlations for the first group of countries
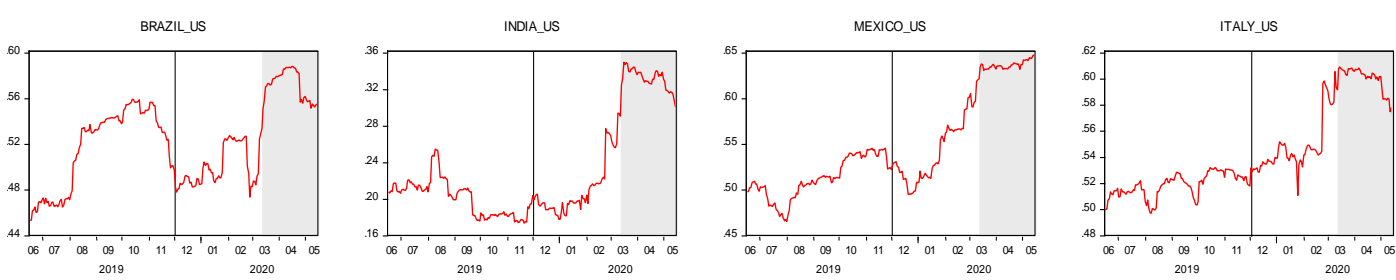

BRAZILINDIA

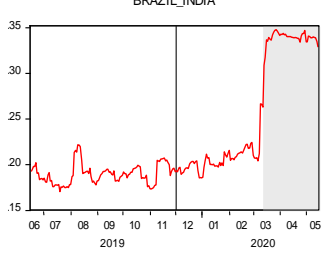

BRAZIL_MEXICO

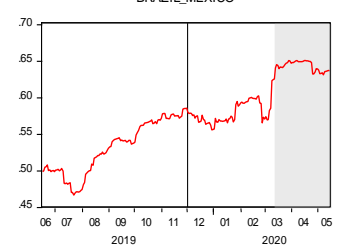

PAZZILITALY

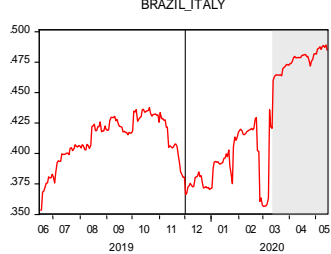

INDIA_MEXICO

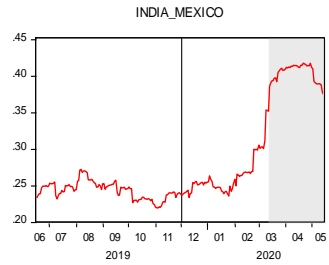

MEXICO_ITALY
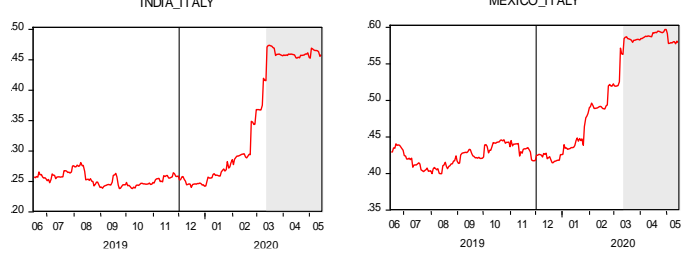

Figure 2: Time-varying conditional correlations for the second group of countries
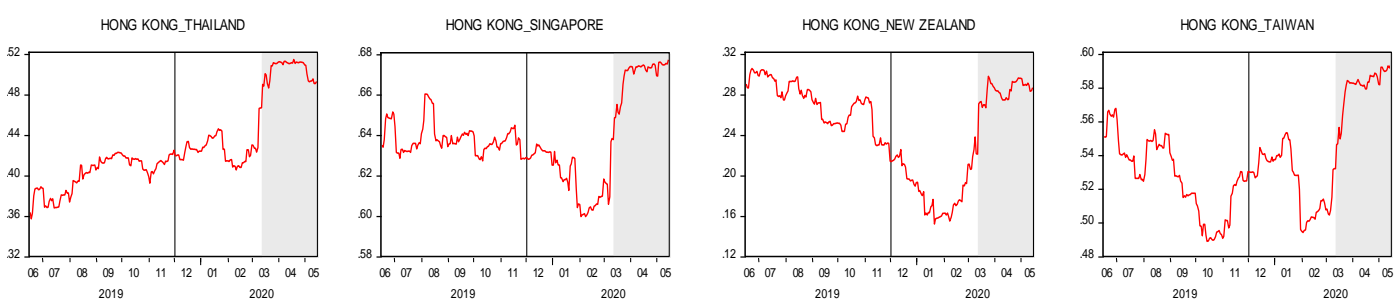

SINGAPORE_THAILAND

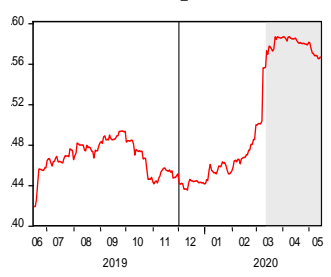

NEW ZEALAND_HHALIAND

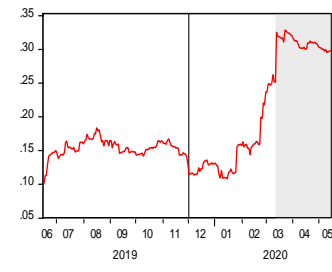

TAIWAN_tHAILAND

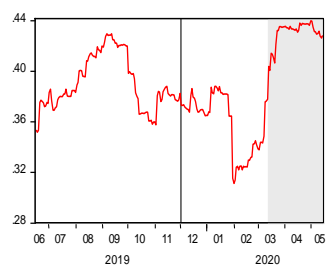

NEW ZEALAND_SINGAPORE

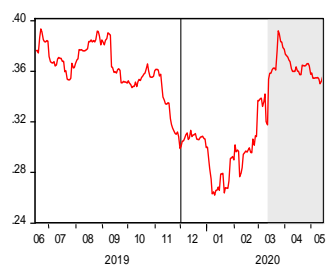

SINGAPORE_TAIWAN
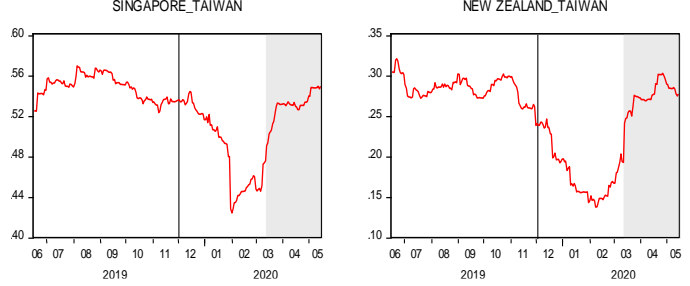

The time-varying pairwise correlations between the countries that have the lowest and highest deaths from Covid-19 are presented in Figure 3 and the results indicate the Covid-19 outbreak precipitated an increase in correlations between pairs of stock markets. More interestingly, although the time-varying correlations 
between stock markets in the pre-Covid-19 period were relatively low for the countries that have the highest and lowest deaths, they started to increase at the beginning of 2020. These findings show that stock markets have exhibited similar patterns from the beginning of 2020 and the Covid-19 outbreak led to an increase in correlations between markets even if the deaths from Covid-19 were low.

Figure 3: Time-varying conditional correlations for the countries that have the highest and lowest deaths

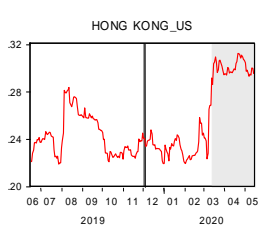

BRAZLL HONG KONG

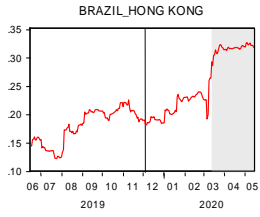

INDIA_HONG KONG

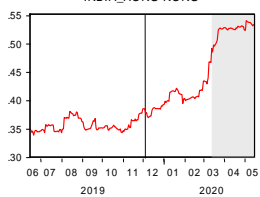

MEXICO_HONG KONG

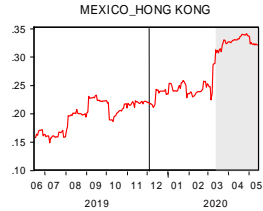

ITALY_HONG KO

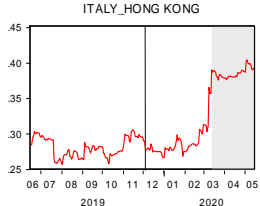

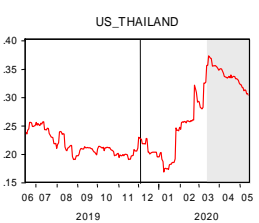

BRAZIL THAILAND

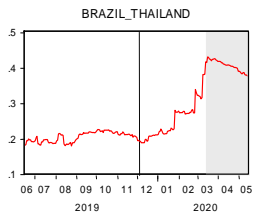

INDIA THAILAND

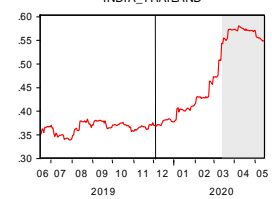

MEXICO_THAILAND

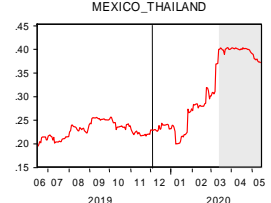

ITALY_THALAND

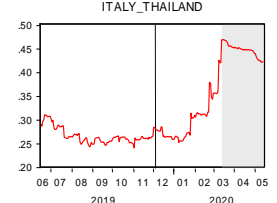

SINGAPORE_US

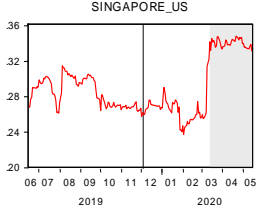

BRAZIL SINGAPORE

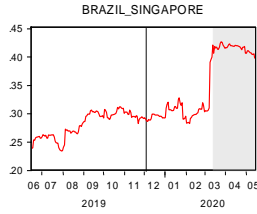

INDIA SINGAPORE

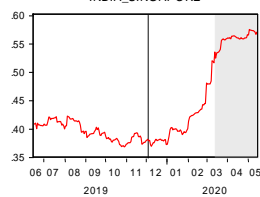

MEXICO_SINGAPORE

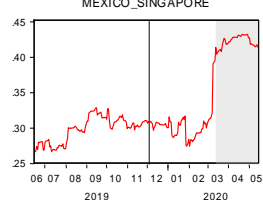

ITALY_SINGAPOR

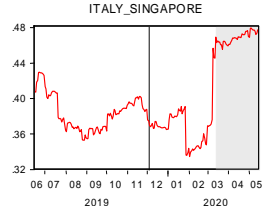

NEW ZEALAND_US

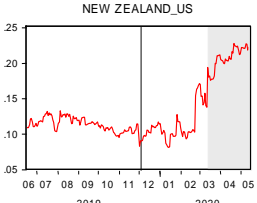

BRAZIL NEW ZEALAND

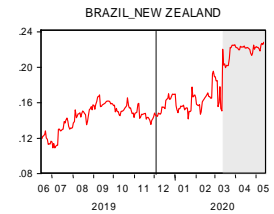

INDIA NEW ZEALAND

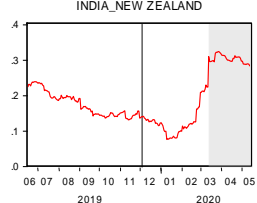

MEXICO_NEW ZEALAND

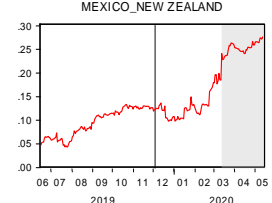

ITALY_NEW ZEALAN

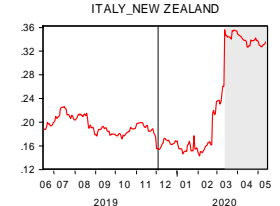

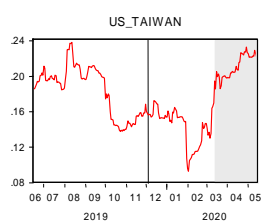

BRAZILTAIWAN

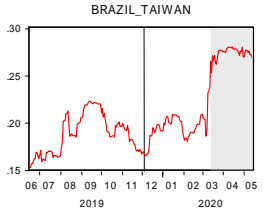

INDIA_TAIWAN

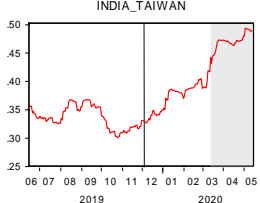

MEXICO_TAIWAN

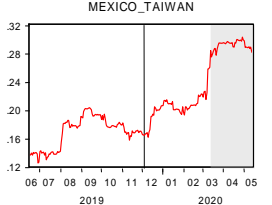

ITALY TAIWAN

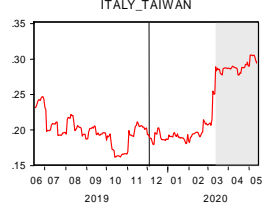

We present the descriptive statistics of the time-varying correlations for both periods and t-test results in Table 4 . The results in Table 4 indicate that the mean of time-varying correlations after Covid-19 outbreak are statistically higher than the mean of time-varying correlations before Covid-19 outbreak in most cases. This implies the contagion analysis reinforces the hypothesis that the correlations between the markets have significantly increased during the global Covid-19 pandemic.

\section{Conclusions}

The aim of the study is to examine the underlying investor sentiment that precipitates contagion in financial markets during the Covid-19 outbreak within a DCC-GARCH model. We split our sample by the number of deaths from Covid19 as of Jan 15, 2021, and separate two groups which have the most deaths (US, 
Brazil, India, Mexico, Italy) and the least deaths (Hong Kong, Thailand, Singapore, New Zealand, Taiwan) The results show that most of the time-varying correlations have risen after the Covid-19 outbreak until the WHO declared the disease as a global pandemic and most of the rise in correlations occurs within each group of countries/regions where the least and the most deaths took place. The t-test results show evidence of contagion in most cases. Overall, this study contributes to our understanding of how investor sentiment may lead to contagion. This reinforces the hypothesis that the correlations between the markets have increased during the global Covid-19 pandemic.

Table 4: Descriptive statistics for the time-varying conditional correlations and contagion effects

\begin{tabular}{|c|c|c|c|c|c|c|c|c|c|c|}
\hline \multirow[b]{3}{*}{ The Most Death } & \multicolumn{4}{|c|}{ Pre COVID-19 (120 days) } & \multicolumn{4}{|c|}{ COVID-19 (120 days) } & \multirow{2}{*}{$\begin{array}{l}\% \\
\text { difference }\end{array}$} & \multirow[t]{2}{*}{ t-test } \\
\hline & Mean & Min. & Max. & Std. Dev. & Mean & Min. & Max. & Std. Dev. & & \\
\hline & & & & & & & & & & \\
\hline US \& Brazil & 0.516 & 0.452 & 0.559 & 0.035 & 0.527 & 0.473 & 0.587 & 0.038 & 2.124 & $-2.360 * *$ \\
\hline US \& India & 0.2 & 0.173 & 0.254 & 0.02 & 0.257 & 0.177 & 0.349 & 0.064 & 28.213 & $-9.416 * * *$ \\
\hline US \& Mexico & 0.512 & 0.464 & 0.545 & 0.022 & 0.578 & 0.494 & 0.646 & 0.053 & 13.041 & $-12.795 * * *$ \\
\hline US \& Italy & 0.518 & 0.496 & 0.531 & 0.009 & 0.567 & 0.51 & 0.608 & 0.031 & 9.497 & $-17.090 * * *$ \\
\hline Brazil \& India & 0.188 & 0.169 & 0.22 & 0.011 & 0.256 & 0.184 & 0.347 & 0.066 & 35.862 & $-11.266 * * *$ \\
\hline Brazil \& Mexico & 0.53 & 0.466 & 0.584 & 0.035 & 0.603 & 0.555 & 0.649 & 0.034 & 13.838 & $-16.395 * * *$ \\
\hline Brazil \& Italy & 0.41 & 0.352 & 0.437 & 0.019 & 0.423 & 0.356 & 0.488 & 0.045 & 3.157 & $-3.041 * * *$ \\
\hline India \& Mexico & 0.242 & 0.218 & 0.271 & 0.012 & 0.316 & 0.233 & 0.416 & 0.073 & 30.331 & $-11.135 * * *$ \\
\hline India \& Italy & 0.252 & 0.236 & 0.279 & 0.01 & 0.35 & 0.238 & 0.472 & 0.094 & 38.832 & $-11.537 * * *$ \\
\hline Mexico \& Italy & 0.423 & 0.398 & 0.444 & 0.013 & 0.509 & 0.413 & 0.595 & 0.069 & 20.259 & $-13.682 * * *$ \\
\hline \multirow[t]{3}{*}{ Group Mean } & \multicolumn{4}{|l|}{0.379} & \multicolumn{4}{|l|}{0.439} & \multirow{3}{*}{$\begin{array}{l}\% \\
\text { difference }\end{array}$} & \\
\hline & \multicolumn{4}{|c|}{ Pre COVID-19 (120 days) } & \multicolumn{4}{|c|}{ COVID-19 (120 days) } & & \multirow[t]{2}{*}{ t-test } \\
\hline & Mean & Min. & Max. & Std. Dev. & Mean & Min. & Max. & Std. Dev. & & \\
\hline \multicolumn{11}{|l|}{ The Least Death } \\
\hline Hong Kong \& Thailand & 0.400 & 0.356 & 0.422 & 0.018 & 0.455 & 0.405 & 0.514 & 0.040 & 13.865 & $-13.814 * * *$ \\
\hline Hong Kong \& Singapore & 0.638 & 0.627 & 0.66 & 0.007 & 0.639 & 0.599 & 0.677 & 0.027 & 0.089 & -.399 \\
\hline Hong Kong \& New Zealand & 0.271 & 0.229 & 0.305 & 0.022 & 0.224 & 0.151 & 0.297 & 0.051 & -17.53 & $9.044 * * *$ \\
\hline Hong Kong \& Taiwan & 0.526 & 0.489 & 0.567 & 0.022 & 0.546 & 0.494 & 0.593 & 0.031 & 3.674 & $-5.727 * * *$ \\
\hline Thailand \& Singapore & 0.467 & 0.418 & 0.493 & 0.016 & 0.506 & 0.434 & 0.586 & 0.061 & 8.428 & $-7.013 * * *$ \\
\hline Thailand \& New Zealand & 0.152 & 0.099 & 0.182 & 0.012 & 0.21 & 0.106 & 0.327 & 0.085 & 38.146 & $-7.574 * * *$ \\
\hline Thailand \& Taiwan & 0.39 & 0.351 & 0.429 & 0.021 & 0.386 & 0.31 & 0.439 & 0.04 & -1.027 & .939 \\
\hline Singapore \& New Zealand & 0.361 & 0.308 & 0.392 & 0.019 & 0.322 & 0.261 & 0.391 & 0.036 & -10.863 & $10.018 * * *$ \\
\hline Singapore \& Taiwan & 0.548 & 0.523 & 0.569 & 0.012 & 0.504 & 0.424 & 0.549 & 0.037 & -7.942 & $12.335 * * *$ \\
\hline New Zealand \& Taiwan & 0.284 & 0.258 & 0.32 & 0.013 & 0.217 & 0.137 & 0.302 & 0.054 & -23.518 & $12.960 * * *$ \\
\hline \multirow[t]{3}{*}{ Group Mean } & 0.404 & & & & 0.401 & & & & & \\
\hline & \multicolumn{4}{|c|}{ Pre COVID-19 (120 days) } & \multicolumn{4}{|c|}{ COVID-19 (120 days) } & $\%$ & t-test \\
\hline & Mean & Min. & Max. & Std. Dev. & Mean & Min. & Max. & Std. Dev. & difference & \\
\hline \multicolumn{11}{|l|}{ The Most and Least Death } \\
\hline US \& Hong Kong & 0.242 & 0.218 & 0.283 & 0.017 & 0.259 & 0.219 & 0.312 & 0.034 & 7.023 & $-4.997 * * *$ \\
\hline US \& Thailand & 0.216 & 0.189 & 0.255 & 0.02 & 0.271 & 0.167 & 0.372 & 0.063 & 25.795 & $-9.445 * * *$ \\
\hline US \& Singapore & 0.284 & 0.26 & 0.314 & 0.015 & 0.293 & 0.236 & 0.347 & 0.039 & 3.198 & $-2.534 * *$ \\
\hline US \& New Zealand & 0.113 & 0.094 & 0.132 & 0.009 & 0.147 & 0.08 & 0.226 & 0.051 & 30.16 & $-7.372 * * *$ \\
\hline US \& Taiwan & 0.183 & 0.137 & 0.237 & 0.028 & 0.169 & 0.092 & 0.232 & 0.037 & -8.016 & $3.345 * * *$ \\
\hline Brazil \& Hong Kong & 0.179 & 0.121 & 0.224 & 0.03 & 0.251 & 0.18 & 0.325 & 0.053 & 40.513 & $-13.060 * * *$ \\
\hline Brazil \& Thailand & 0.203 & 0.178 & 0.224 & 0.014 & 0.307 & 0.186 & 0.429 & 0.087 & 51.139 & $-13.046 * * *$ \\
\hline Brazil \& Singapore & 0.279 & 0.232 & 0.31 & 0.022 & 0.345 & 0.281 & 0.425 & 0.057 & 23.853 & $-12.079 * * *$ \\
\hline
\end{tabular}




\begin{tabular}{|c|c|c|c|c|c|c|c|c|c|c|}
\hline Brąil \& New Zealand & 0.142 & 0.108 & 0.168 & 0.015 & 0.182 & 0.14 & 0.227 & 0.03 & 27.883 & $-13.018 * * *$ \\
\hline Brazil \& Taiwan & 0.188 & 0.152 & 0.222 & 0.021 & 0.224 & 0.164 & 0.28 & 0.041 & 19.494 & $-9.033 * * *$ \\
\hline India \& Hong Kong & 0.355 & 0.337 & 0.379 & 0.011 & 0.449 & 0.369 & 0.539 & 0.061 & 26.678 & $-16.771 * * *$ \\
\hline India \& Thailand & 0.363 & 0.337 & 0.381 & 0.011 & 0.469 & 0.366 & 0.578 & 0.08 & 29.302 & $-14.557 * * *$ \\
\hline India \& Singapore & 0.395 & 0.367 & 0.421 & 0.016 & 0.466 & 0.368 & 0.574 & 0.078 & 17.992 & $-9.968 * * *$ \\
\hline India \& New Zealand & 0.174 & 0.129 & 0.236 & 0.033 & 0.192 & 0.073 & 0.321 & 0.091 & 10.673 & $-2.302 * *$ \\
\hline India \& Taiwan & 0.335 & 0.3 & 0.366 & 0.02 & 0.407 & 0.324 & 0.492 & 0.054 & 21.754 & $-14.268 * * *$ \\
\hline Mexico \& Hong Kong & 0.195 & 0.147 & 0.231 & 0.025 & 0.272 & 0.209 & 0.339 & 0.044 & 39.469 & $-16.848 * * *$ \\
\hline Mexico \& Thailand & 0.227 & 0.193 & 0.254 & 0.016 & 0.308 & 0.197 & 0.402 & 0.075 & 35.865 & $-11.820 * * *$ \\
\hline Mexico \& Singapore & 0.297 & 0.265 & 0.327 & 0.018 & 0.348 & 0.273 & 0.431 & 0.06 & 17.17 & $-8.956 * * *$ \\
\hline Mexico \& New Zealand & 0.092 & 0.041 & 0.131 & 0.029 & 0.175 & 0.096 & 0.274 & 0.065 & 89.656 & $-12.769 * * *$ \\
\hline Mexico \& Taiwan & 0.168 & 0.125 & 0.203 & 0.022 & 0.236 & 0.161 & 0.303 & 0.046 & 40.489 & $-14.903 * * *$ \\
\hline Italy \& Hong Kong & 0.28 & 0.255 & 0.304 & 0.013 & 0.324 & 0.265 & 0.403 & 0.05 & 15.85 & $-9.396 * * *$ \\
\hline Italy \& Thailand & 0.264 & 0.239 & 0.309 & 0.017 & 0.354 & 0.251 & 0.468 & 0.081 & 33.776 & $-12.098 * * *$ \\
\hline Italy \& Singapore & 0.383 & 0.352 & 0.428 & 0.02 & 0.406 & 0.333 & 0.478 & 0.052 & 5.887 & $-4.582 * * *$ \\
\hline Italy \& New Zealand & 0.193 & 0.17 & 0.225 & 0.013 & 0.235 & 0.141 & 0.354 & 0.085 & 21.627 & $-5.457 * * *$ \\
\hline Italy \& Taiwan & 0.198 & 0.16 & 0.246 & 0.02 & 0.23 & 0.178 & 0.304 & 0.047 & 16.419 & $-7.134 * * *$ \\
\hline Group Mean & 0.238 & & & & 0.293 & & & & & \\
\hline
\end{tabular}

Note: $* * *$ indicates statistically significant test statistic at $1 \%$ level.

\section{References}

Akhtaruzzaman, M., Boubaker, S., \& Sensoy, A. (2021). Financial contagion during COVID-19 crisis. Finance Research Letters, 38, 101604. https://doi.org/10.1016/j.frl.2020.101604

Corbet, S., Larkin, C., \& Lucey, B. (2020). The contagion effects of the COVID-19 pandemic: Evidence from Gold and Cryptocurrencies. Finance Research Letters, 101554. https://doi.org/10.1016/j.frl.2020.101554

Corredor, P., Ferrer, E., \& Santamaria, R. (2013). Investor sentiment effect in stock markets: Stock characteristics or country-specific factors? International Review of Economics \& Finance, 27, 572-591. https://doi.org/10.1016/j.iref.2013.02.001

Çütcü, İ., \& K1lıç, Y. (2020). Stock Market Response to Coronavirus (COVID-19) Pandemic. Journal of Applied Economics \& Business Research, 10(4), 207-220.

Debata, B., Dash, S. R., \& Mahakud, J. (2018). Investor sentiment and emerging stock market liquidity. Finance Research Letters, 26, 15-31. https://doi.org/10.1016/j.frl.2017.11.006

Engle, R. (2002). Dynamic Conditional Correlation. Journal of Business \& Economic Statistics, 20(3), 339-350. https://doi.org/10.1198/073500102288618487

Huang, W., \& Zheng, Y. (2020). COVID-19: Structural Changes in the Relationship between Investor Sentiment and Crude Oil Futures Price. Energy Research Letters, 1(2), 13685. https://doi.org/10.46557/001c.13685 
Johnston, W. M., \& Davey, G. C. L. (1997). The psychological impact of negative TV news bulletins: The catastrophizing of personal worries. British Journal of Psychology, 88(1), 85-91. https://doi.org/10.1111/j.20448295.1997.tb02622.x

Kaplanski, G., \& Levy, H. (2010). Sentiment and stock prices: The case of aviation disasters. Journal of Financial Economics, 95(2), 174-201. https://doi.org/10.1016/j.jfineco.2009.10.002

Khan, M. A., Hernandez, J. A., \& Shahzad, S. J. H. (2019). Time and frequency relationship between household investors' sentiment index and US industry stock returns. Finance Research Letters, 101318. https://doi.org/10.1016/j.frl.2019.101318

Naseem, S., Mohsin, M., Hui, W., Liyan, G., \& Penglai, K. (2021). The Investor Psychology and Stock Market Behavior during the Initial Era of COVID19: A Study of China, Japan, and the United States. Frontiers in Psychology, 12, 1-10. https://doi.org/10.3389/fpsyg.2021.626934.

Niţoi, M., \& Pochea, M. M. (2020). Time-varying dependence in European equity markets: A contagion and investor sentiment driven analysis. Economic Modelling, 86, 133-147. https://doi.org/10.1016/j.econmod.2019.06.007

Peterson, P. P. (1989). Event Studies: A Review of Issues and Methodology. Quarterly Journal of Business and Economics, 28(3), 36-66. JSTOR.

Shan, L., \& Gong, S. X. (2012). Investor sentiment and stock returns: Wenchuan Earthquake. Finance Research Letters, 9(1), 36-47. https://doi.org/10.1016/j.frl.2011.07.002

Kılıç, Y. (2020). Borsa İstanbul'da COVID-19 (Koronavirüs) Etkisi. JOEEP: Journal of Emerging Economies and Policy, 5(1), 66-77. Retrieved from https://dergipark.org.tr/en/pub/joeep/issue/53777/734904

Xia, Z., \& Chen, J. (2021). Mining the Relationship between COVID-19 Sentiment and Market Performance. ArXiv:2101.02587 [Econ, q-Fin], 1-18.

Yeo, L. H. (2020). Impact of Covid-19 pandemic on Asia-Europe relations. Asia Europe Journal, 1-4. https://doi.org/10.1007/s10308-020-00575-2

Zhang, D., Hu, M., \& Ji, Q. (2020). Financial markets under the global pandemic of COVID-19. Finance Research Letters, 101528. https://doi.org/10.1016/j.frl.2020.101528

Zhao, L., Wang, J., Huang, R., Cui, H., Qiu, X., \& Wang, X. (2014). Sentiment contagion in complex networks. Physica A: Statistical Mechanics and Its Applications, 394, 17-23. https://doi.org/10.1016/j.physa.2013.09.057. 
Appendix: Descriptive statistics of time-varying conditional correlations (full sample)

\begin{tabular}{lllll}
\hline \hline The Most Death & Mean & Max. & Min. & Std. Dev. \\
\hline US \& Brazil & 0.56 & 0.711 & 0.381 & 0.082 \\
US \& India & 0.246 & 0.399 & 0.133 & 0.051 \\
US \& Mexico & 0.609 & 0.737 & 0.424 & 0.078 \\
US \& Italy & 0.51 & 0.629 & 0.374 & 0.053 \\
Brazil \& India & 0.287 & 0.415 & 0.155 & 0.054 \\
Brazil \& Mexico & 0.648 & 0.753 & 0.465 & 0.064 \\
Brazil \& Italy & 0.476 & 0.642 & 0.273 & 0.081 \\
India \& Mexico & 0.318 & 0.47 & 0.159 & 0.065 \\
India \& Italy & 0.34 & 0.475 & 0.191 & 0.061 \\
Mexico \& Italy & 0.526 & 0.655 & 0.385 & 0.066 \\
Group Mean & 0.452 & & & 0.066 \\
\hline & & & & \\
\hline The Least Death & Mean & Max. & Min. & Std. Dev. \\
\hline Hong Kong \& Thailand & 0.433 & 0.582 & 0.274 & 0.066 \\
Hong Kong \& Singapore & 0.624 & 0.723 & 0.414 & 0.059 \\
Hong Kong \& New Zealand & 0.297 & 0.476 & 0.124 & 0.069 \\
Hong Kong \& Taiwan & 0.538 & 0.636 & 0.354 & 0.048 \\
Thailand \& Singapore & 0.488 & 0.623 & 0.293 & 0.066 \\
Thailand \& New Zealand & 0.243 & 0.394 & 0.093 & 0.062 \\
Thailand \& Taiwan & 0.389 & 0.491 & 0.227 & 0.042 \\
Singapore \& New Zealand & 0.385 & 0.543 & 0.243 & 0.059 \\
Singapore \& Taiwan & 0.521 & 0.62 & 0.306 & 0.056 \\
New Zealand \& Taiwan & 0.277 & 0.434 & 0.12 & 0.063 \\
\hline Group Mean & 0.419 & & & 0.059 \\
\hline
\end{tabular}


Appendix: Descriptive statistics of time-varying conditional correlations (full sample)

\begin{tabular}{lllll}
\hline \hline The Most and Least Death & Mean & Max. & Min. & Std. Dev. \\
\hline US \& Hong Kong & 0.215 & 0.336 & 0.112 & 0.038 \\
US \& Thailand & 0.21 & 0.371 & 0.06 & 0.049 \\
US \& Singapore & 0.27 & 0.404 & 0.137 & 0.059 \\
US \& New Zealand & 0.168 & 0.333 & 0.003 & 0.072 \\
US \& Taiwan & 0.162 & 0.312 & 0.038 & 0.049 \\
Brazil \& Hong Kong & 0.261 & 0.38 & 0.12 & 0.053 \\
Brazil \& Thailand & 0.255 & 0.428 & 0.139 & 0.057 \\
Brazil \& Singapore & 0.343 & 0.48 & 0.186 & 0.065 \\
Brazil \& New Zealand & 0.249 & 0.401 & 0.058 & 0.072 \\
Brazil \& Taiwan & 0.225 & 0.372 & 0.089 & 0.048 \\
India \& Hong Kong & 0.433 & 0.543 & 0.323 & 0.048 \\
India \& Thailand & 0.423 & 0.578 & 0.264 & 0.06 \\
India \& Singapore & 0.484 & 0.609 & 0.314 & 0.066 \\
India \& New Zealand & 0.25 & 0.403 & 0.072 & 0.063 \\
India \& Taiwan & 0.387 & 0.493 & 0.283 & 0.04 \\
Mexico \& Hong Kong & 0.26 & 0.395 & 0.096 & 0.051 \\
Mexico \& Thailand & 0.284 & 0.419 & 0.136 & 0.056 \\
Mexico \& Singapore & 0.37 & 0.514 & 0.227 & 0.06 \\
Mexico \& New Zealand & 0.252 & 0.394 & 0.037 & 0.079 \\
Mexico \& Taiwan & 0.218 & 0.379 & 0.1 & 0.053 \\
Italy \& Hong Kong & 0.289 & 0.426 & 0.132 & 0.051 \\
Italy \& Thailand & 0.286 & 0.468 & 0.116 & 0.064 \\
Italy \& Singapore & 0.41 & 0.549 & 0.242 & 0.063 \\
Italy \& New Zealand & 0.298 & 0.469 & 0.107 & 0.087 \\
Italy \& Taiwan & 0.224 & 0.365 & 0.097 & 0.048 \\
\hline Group Mean & 0.289 & & & 0.058 \\
\hline
\end{tabular}

